\title{
A Case Study on the Particularities and Sustainability of the Concepts of TQM, Quality Control, and Risk Management in the Corporate Insurance Industry: Loss and the Incidence of Catastrophic Risks ${ }^{\dagger}$
}

\author{
Narcis Sebastian Păvălașcu and Manuela Rozalia Gabor *(i) \\ “G.E. Palade" University of Medicine, Pharmacy, Sciences and Technology of Târgu Mureș, \\ 540142 Târgu Mureș, Romania; narcis@pavalascu.com \\ * Correspondence: manuela.gabor@umfst.ro \\ † Presented at the 14th International Conference on Interdisciplinarity in Engineering-INTER-ENG 2020, \\ Târgu Mures, Romania, 8-9 October 2020.
}

Published: 10 December 2020

\begin{abstract}
The development of quality control and risk management systems is a priority for any industry and especially for the corporate insurance industry. Defective product and work incidents represent $14 \%$ of the total number of insurance claims, serving as the main loss of liability for businesses. According to a Allianz Global Corporate and Specialty press release, the cyber risks and impact of new technologies will have an increasing influence on the landscape of corporate losses in the coming years. Our results from this study conclude that the emerging business risks for the next 3-4 years are as follows: cyber incidents, 48\%; new technologies, 30\%; and changes in legislations/regulations, $28 \%$ (i.e., the present pandemic cause by COVID-19, the Brexit, trade wars, and tariffs etc.).
\end{abstract}

Keywords: cyber risk; loss adjustments; corporate insurance industry; risk management; quality control

\section{Introduction}

The development of quality control and risk management systems is a priority [1] for any industry and especially for the corporate insurance industry. The Allianz Global Corporate and Specialty (AGCS) report [2] highlights the ascension of defective products in 2018 compared to 2014 [3] (Table 1). Defections rose from the ninth to the fifth largest loss incurred by companies worldwide. Defective products and work incidents account for $14 \%$ of the aggregate value of claims paid out to businesses, and are as such a root cause of liability losses. Risk management involves the assessment of risks facing an organization. Some risks can be avoided, but what remains must be borne by the organization or transferred through insurance [4].

The core causes of products being defective include, according to the Allianz Report 2018 [2]: product recalls, costs of defect repairs in the car-making industry, revenue loss due to businesses shutting down as a result of a significant percentage of defective products being delivered, food contamination, allergens etc.

Trends such as globalization and industry consolidation are conducive to growing claims on insurance policies covering multiple jurisdictions, according to the Allianz Report 2014 [3]. According to European Insurance [5], the insurance sector is the single largest institutional investor in the EU with more than EUR 10 bn in managed assets invested across the economy in 2017, which equals to $63 \%$ of the EU's GDP [5]. 
Table 1. The top causes for business losses in 2018 (a) and 2014 (b).

\begin{tabular}{|c|c|c|c|c|}
\hline \multicolumn{3}{|c|}{ Top Causes of Loss by Total Value of Claims (2013-2018) (a) } & \multicolumn{2}{|c|}{ Top Causes of Loss by Total Value (2009-2013) (b) } \\
\hline 1 & Fire/explosion & $24 \%$ & 1 & Grounding \\
\hline 2 & Aviation collision/crash & $14 \%$ & 2 & Fire \\
\hline 3 & Faulty workmanship/maintenance & $8 \%$ & 3 & Aviation crash \\
\hline 4 & Storm & $7 \%$ & 4 & Earthquake \\
\hline 5 & Defective products & $6 \%$ & 5 & Storm \\
\hline 6 & $\begin{array}{c}\text { Damaged goods } \\
\text { (including handlings/storage) }\end{array}$ & $5 \%$ & 6 & $\begin{array}{c}\text { Bodily injury } \\
\text { (including fatalities) }\end{array}$ \\
\hline 7 & $\begin{array}{l}\text { Machinery breakdown } \\
\text { (including engine failure) }\end{array}$ & $5 \%$ & 7 & Flood \\
\hline 8 & Water damage & $3 \%$ & 8 & Professional indemnity \\
\hline 9 & Ship sinking/collision & $2 \%$ & 9 & Product defects \\
\hline 10 & $\begin{array}{l}\text { Professional indemnity } \\
\text { (e.g., negligence/bad advice) }\end{array}$ & $2 \%$ & 10 & Machinery breakdown \\
\hline
\end{tabular}

Further causes that result in big business losses in various industries include:

- Business disruption as a result of natural disasters (flood, earthquake, fire etc.).

- Business disruption because of terrorist acts. Products sold in the insurance industry also include policies that cover losses caused by acts of terrorism.

- Business disruption because of cyberattacks, as products sold in the insurance industry also include policies that cover losses caused by cyberattacks.

- Environmental liability insurance and losses from industrial accidents, which affect the environment [6].

- Third party liability insurance for nuclear, oil, and gas operations [6], with Romania yet to develop this sector as its experience/expertise in the area is limited.

- Other business sector insurance covers losses caused by [7] a loss of key personnel, risk management, green business [8], terrorism, insurance against kidnapping of a company's managing team or key personnel, etc.

The latest business insurance packages included terrorism insurance [9].

According to a press release issued by AGCS, which from 2013 to 2018 covered 470,000 global insurance claims from more than 200 countries, cyber risks and new technologies' impact will increasingly affect the landscape of corporate losses over the coming years. However, fire and explosion incidents cause the highest claims to insurers, according to recent AGCS research. Most corporate insurance claims arise from technical or human factors rather than natural disasters, such as hurricanes, that inflicted devastating losses over the past two years.

The top perils for companies in 2019 include the following hierarchy (in terms of criticality):

1. Business interruption (discontinuation of business because of various causes), $37 \%$ down from $2018(42 \%)$;

2. Cyber incidents, 37\% down from $2018(40 \%)$;

3. Catastrophes attributable to natural causes, $28 \%$ down from $2018(30 \%)$;

4. Changes in laws and regulations, $27 \%$ up from $2018(21 \%)$;

5. Market development, $23 \%$ slightly up from $2018(22 \%)$;

6. Fires and explosion, $19 \%$ very similar to $2018(20 \%)$;

7. New technologies, $19 \%$ up from 2018 (15\%);

8. Climate changes/increasing volatility of weather, $13 \%$ up from $2018(10 \%)$;

9. Loss of reputation or brand value, $13 \%$ as high as in 2018;

10. Lack of a skilled labor force, $9 \%$ highlighted by AGCS as a new risk cause in insurance in 2019 as compared to previous years.

Technology creates new threats and business models. Traditional risks such as natural disasters still occur, whereas other threats, such as cybercrimes, are on a par with business interruption and top the 
Allianz risk chart. For the first time, there have been daily rises in reputational risk, increasing exposure to intangible assets, and volatility and consolidation in the corporate environment. Yet, looking at the future, new technologies bring businesses benefits, risks, and liabilities. However, new technologies also provide an opportunity to prevent and minimize losses and to improve the claim settlement process for corporate customers. The analysis reveals that corporate insurance claims usually are originated by technical or human factors-or non-natural catastrophic events-accounting for $87 \%$ of the value of total claims.

\section{International Trends in Occurrence of Catastrophic Risks-Statistics and Facts}

In the opinion of the National Union of Insurance and Reinsurance Companies in Romania (UNSAR) [6], the rate of penetration for catastrophe insurance in the EU differs across countries, with legislation on natural disaster insurance and people's education in risk awareness acting as major causative factors. Due to the patchiness of the EU Member States, more thorough research is required to comprehend the specific traits of each country in order to create suitable risk coverage, or coverage layers better suited to the needs of each individual country.

The past 20 years have seen a significant rise in both frequency and impact of disaster type events, which raised concerns in the world insurance industry. Significant (both material and human) losses have been in the public eye and generated governmental efforts to have them covered up, particularly when losses were not insured/insurable. Earthquakes, fires, landslides, or floods all resulted in a financial, social, economic, and political impact in the affected areas [10].

An analysis of the economic losses and insured losses from 1950-2018 worldwide were conducted by Radu and Naghi [11]. The analysis is presented in Table 2, which contains the statistical data supporting this analysis.

Table 2. Analysis of 10-year periods of natural disaster impacts (USD billion in 2018).

\begin{tabular}{|c|c|c|c|c|c|c|c|}
\hline & 1950-1959 & 1960-1969 & 1970-1979 & 1980-1989 & 1990-1999 & $2000-2009$ & 2010-2018 \\
\hline Number of events & 292 & 547 & 839 & 1653 & 2577 & 3861 & 2988 \\
\hline Economic losses & 6058 & 18,445 & 17,181 & 53,845 & 746,015 & 892,312 & $1,354,014$ \\
\hline Insured losses & 0.033 & 0.066 & 0.113 & 0.239 & 98.8 & 479 & 739 \\
\hline Damage rate of economic losses & 0.54 & 0.36 & 0.66 & 0.44 & 13.24 & 53.68 & 54.58 \\
\hline Average damage on the event & 0.020747 & 0.0337203 & 0.0204779 & 0.0325741 & 0.28949 & 0.231109 & 0.453151 \\
\hline Average insured damage on the event & 0.000113 & 0.0001207 & 0.0001347 & 0.0001446 & 0.038339 & 0.124061 & 0.247323 \\
\hline
\end{tabular}

Source: [11].

A Munich Re research combined with the AON Report 2018 revealed that during 1988-1997, the global economy incurred USD 700 bn as a result of catastrophic events in the region, while such costs amounted to approximately USD 4000 bn over the last two decades (2000-2018), as opposed to the numbers in 2018. The second half of the 20th century saw 250 large scale natural disasters. As shown by the data in Table 1, the loss coverage rate provides a measure of how economic losses are recovered due to insurance coverage. During the periods under review, this rate has seen a notable rise (doubling in value), indicating that the insurance transfer method has seen steady rises; therefore, this supports specialist companies' acknowledgment of natural disaster events.

Because there are a visible number of increasing events and values for the variables in Table 1 , we used a statistical method (Student's t-test) with SPSS statistical software the mean of values by grouping: after/before 1990 and after/before 2000. The results from Tables 3 and 4 show that there are statistically significant differences for these variables grouped from the years 1990 and 2000. 
Table 3. ANOVA for the group before/after 1990.

\begin{tabular}{|c|c|c|c|c|c|c|}
\hline & & $\begin{array}{l}\text { Sum of } \\
\text { Squares }\end{array}$ & df & $\begin{array}{l}\text { Mean } \\
\text { Square }\end{array}$ & $\mathbf{F}$ & Sig. \\
\hline \multirow{3}{*}{ Number of events } & Between Groups & $9,141,660.964$ & 1 & $9,141,660.964$ & 23,971 & 0.004 \\
\hline & Within Groups & $1,906,814.750$ & 5 & $381,362.950$ & & \\
\hline & Total & $1.105 \times 10^{7}$ & 6 & & & \\
\hline \multirow{3}{*}{ Economic losses } & Between Groups & $1.625 \times 10^{12}$ & 1 & $1.625 \times 10^{12}$ & 40,080 & 0.001 \\
\hline & Within Groups & $2.027 \times 10^{11}$ & 5 & $4.054 \times 10^{10}$ & & \\
\hline & Total & $1.828 \times 10^{12}$ & 6 & & & \\
\hline \multirow{3}{*}{ Insured losses } & Between Groups & $330,108.865$ & 1 & $330,108.865$ & 7961 & 0.037 \\
\hline & Within Groups & $207,336.051$ & 5 & $41,467.210$ & & \\
\hline & Total & $537,444.916$ & 6 & & & \\
\hline \multirow{3}{*}{$\begin{array}{l}\text { Coverage rate for } \\
\text { economic losses }\end{array}$} & Between Groups & 2742.857 & 1 & 2742.857 & 12,299 & 0.017 \\
\hline & Within Groups & 1115.117 & 5 & 223.023 & & \\
\hline & Total & 3857.974 & 6 & & & \\
\hline \multirow{3}{*}{$\begin{array}{c}\text { Average damage } \\
\text { per event }\end{array}$} & Between Groups & 0.152 & 1 & 0.152 & 28,498 & 0.003 \\
\hline & Within Groups & 0.027 & 5 & 0.005 & & \\
\hline & Total & 0.179 & 6 & & & \\
\hline \multirow{3}{*}{$\begin{array}{l}\text { Average damage } \\
\text { insured per event }\end{array}$} & Between Groups & 0.032 & 1 & 0.032 & 7230 & 0.043 \\
\hline & Within Groups & 0.022 & 5 & 0.004 & & \\
\hline & Total & 0.054 & 6 & & & \\
\hline
\end{tabular}

Source: own calculations with SPSS program based on data from [10].

Table 4. ANOVA for the group before/after 2000.

\begin{tabular}{|c|c|c|c|c|c|c|}
\hline & & $\begin{array}{l}\text { Sum of } \\
\text { Squares }\end{array}$ & df & $\begin{array}{l}\text { Mean } \\
\text { Square }\end{array}$ & $\mathbf{F}$ & Sig. \\
\hline \multirow{3}{*}{ Number of events } & Between Groups & $7,186,572.014$ & 1 & $7,186,572.014$ & 9.304 & 0.028 \\
\hline & Within Groups & $3,861,903.700$ & 5 & $772,380.740$ & & \\
\hline & Total & $1.105 \times 10^{7}$ & 6 & & & \\
\hline \multirow{3}{*}{ Economic losses } & Between Groups & $1.302 \times 10^{12}$ & 1 & $1.302 \times 10^{12}$ & 12.403 & 0.017 \\
\hline & Within Groups & $5.251 \times 10^{11}$ & 5 & $1.050 \times 10^{11}$ & & \\
\hline & Total & $1.828 \times 10^{12}$ & 6 & & & \\
\hline \multirow{3}{*}{ Insured losses } & Between Groups & $495,853.553$ & 1 & $495,853.553$ & 59.610 & 0.001 \\
\hline & Within Groups & $41,591.363$ & 5 & 8318.273 & & \\
\hline & Total & $537,444.916$ & 6 & & & \\
\hline \multirow{3}{*}{$\begin{array}{l}\text { Coverage rate for } \\
\text { economic losses }\end{array}$} & Between Groups & 3727.672 & 1 & 3727.672 & 143.040 & 0.000 \\
\hline & Within Groups & 130.301 & 5 & 26.060 & & \\
\hline & Total & 3857.974 & 6 & & & \\
\hline \multirow{3}{*}{$\begin{array}{c}\text { Average damage } \\
\text { per event }\end{array}$} & Between Groups & 0.099 & 1 & 0.099 & 6.165 & 0.056 \\
\hline & Within Groups & 0.080 & 5 & 0.016 & & \\
\hline & Total & 0.179 & 6 & & & \\
\hline \multirow{3}{*}{$\begin{array}{l}\text { Average damage } \\
\text { insured per event }\end{array}$} & Between Groups & 0.045 & 1 & 0.045 & 25.798 & 0.004 \\
\hline & Within Groups & 0.009 & 5 & 0.002 & & \\
\hline & Total & 0.054 & 6 & & & \\
\hline
\end{tabular}

Source: own calculations with SPSS program based on data from [10].

This trend in conjunction with the rising economic losses led us to conclude that, within the 70 years under review, the difference between the insured losses and uninsured losses decreased steadily, which confirmed that insurance covered these economic losses. 


\section{Particularities and Applications of the Corporate Insurance Industry: Total Quality Management (TQM) and Quality Control Globally and in Romania}

Total quality management (TQM) has a host of definitions [12] but it is basically a quality management system that provides support for the continued improvement of products or services with zero defects. The advantages and benefits of implementing TQM in the insurance industry include [12] an increased market share, improved profitability, long-term cost-cutting [13], skilling and retaining company employees [14], heightened productivity, an innovative work environment, and a value-added difference.

The service and financial sector have been slow to implement the TQM principles for several reasons [15]:

- Quality and productivity policies are less clear than in the production sector.

- Service and financial companies are often shielded against international competitors under regulations, protection legislation, and cultural barriers.

- Financial institutions, particularly insurance companies, make promises that often are made good on only after a significant amount of time.

TQM is capable of defining, spotting, and prioritizing exceptional conditions that require a management decision [15]. This is the most compelling reason why a company's Actuarial Department should be the most informed and active participants in any TQM effort [15].

Big damage reports amount to a successful approach to this issue, yet they come with the downside of dealing only with cases that have already occurred. In this case, TQM's imperative is to limit management changes that may affect the claim settlement workflow to those changes that are required and supported by proof or are simply inevitable. The Actuarial Department is faced with the challenge of needing to interpret and use the monitoring data provided by the claim department to improve the accuracy and dynamic reaction of the actuarial projections [15].

There are countries in the world, such as Palestine [16], which have conducted research on key activities to ensure that the TQM concept is successfully implemented by insurance companies across the country [16]. A second example is Oman [17], which put together a "manual guide for minimal quality assurance standards for services provided to clients of brokers and insurance companies", which contains precise provisions for each individual aspect. It puts forth several quality standards based on the type of service provided by the insurance firm [17]. Another specific example of how to implement the TQM concept in the insurance industry is what has occurred in Indonesia [12], where an emphasis is placed on the fact that the insurance industry increasingly uses new channels for new technologies and tools. Authors have reviewed how TQM has been implemented in an insurance company that offered the following services: worker compensation, defective machinery, all-risk contractors, safe cash, cash-in-transit, and third-party liability.

Experience of insurance loss adjusters shows that insurance companies often use their QA (Quality Assurance) audit mission aggressively to deter what auditors describe as "inflated payments". In other words, one of the things sought by a QA auditor is the amount of money paid by a loss adjuster for a claim, irrespective of whether that amount is too small, fair, or too big [18].

Another insurance expert, Sandquist [19], focused on the implementation of Kaizen and TQM in the insurance industry. Sandquist claimed that focus on product quality, when used in insurance marketing, implies seeing beyond a product's features to better understand customers' insurance needs. Telematics is a means used by leading insurers to achieve this.

Examples of top ISO-certified insurance companies that successfully implemented TQM should include the US global Crawford and Company, which represents 70 countries, including Romania, who periodically uses press releases to inform which of its branches or representative offices has become ISO 9001:2000 certified (i.e., entities in the Netherlands [20] or Australia [21] for ISO 27001 for information security management system (ISMS) in the wake of an audit work by Lloyd's Register Quality Assurance). 
As far as the concept of risk management is concerned, it is internationally recognized that, in the insurance industry, wide principles that should be embedded into a risk management framework are provided covering the strategy, organizational structure, policies, and procedures related to the management of the implicit risks in such business [11]. To achieve this, the Monetary Authority of Singapore [22] has proposed an entire process to address those risks generated by core insurance activities, including product development, pricing, underwriting, claim handling, and reinsurance management. Moreover, with regard to risk evaluation, the consulting firm KPMG offers the following recommendations [23]: understanding the entity; a plan to engage in-house and third party experts; internal audit; service providers and other auditors as required; evaluation of the relevant designs and implementation of the relevant controls; arranging talks to evaluate and plan risks; identification of audit strategy; and planning the required audit approach.

\section{Conclusions}

Over the last few years, natural catastrophic events have inflicted more losses upon economies around the world. Global climate changes, whether or not as a result of human activities, and the growing population density, mostly in the exposed areas, are the top causes responsible for the growing volume of economic losses both in developed countries and in those with an emerging economy. The more developed the economy of a region, the bigger the economic losses caused by catastrophes.

In terms of how a market can recover from such economic losses, a significant role is played by insurance, reinsurance, and capital market. The insurance and reinsurance industry is therefore faced with an enormous challenge: to identify solutions to manage issues posed by the growing impact of natural disasters around the world. This is clarified by one of the proposals in the TQM-quality control-risk management consolidation.

Thus, the seven conventional quality control tools can also be used in the corporate insurance industry, i.e., Pareto charts, cause-and-effect diagrams (fishbone diagram), histograms, control diagrams, scatter diagrams, inspection checklists, and the stratification method. Moreover, J. Chen and J.-H. Chen proposed, in 2011 [24], a model for risk management (Figure 1), which can be also applied in the insurance industry.

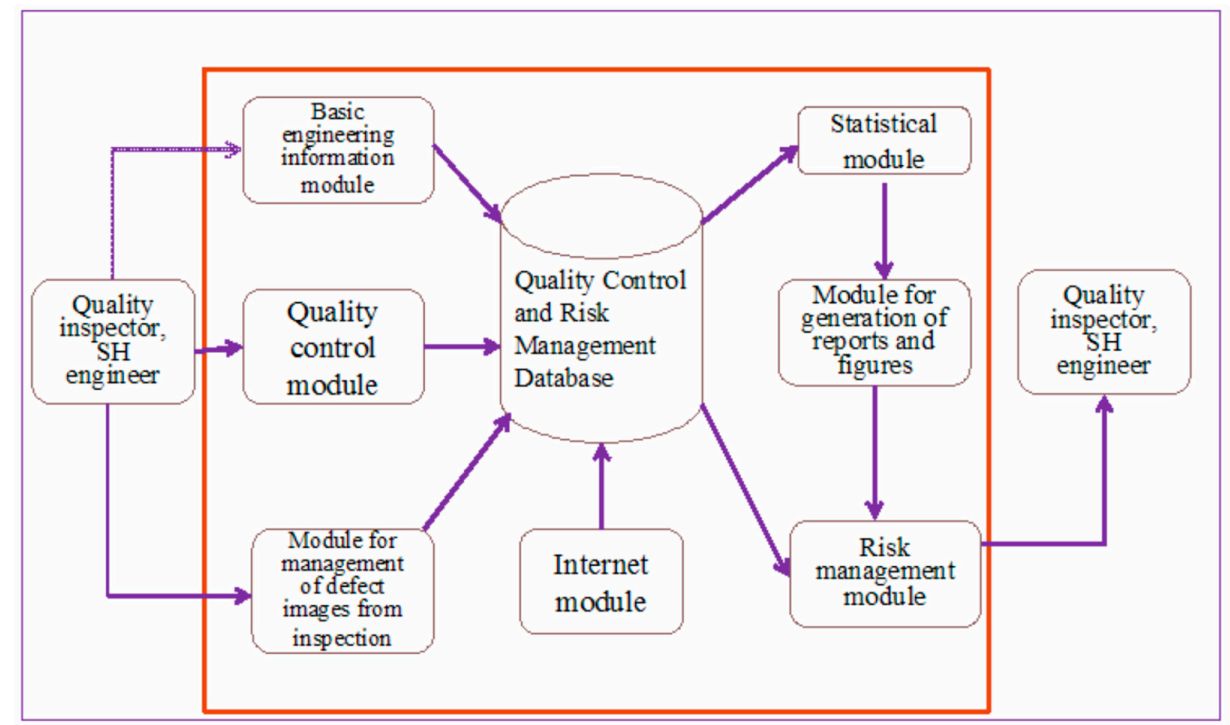

Figure 1. Model suggested by J. Chen and J.-H. Chen [24] for risk management.

An innovative solution contributed by UNSAR (The National Association of Insurance and Reinsurance Companies in Romania) is parametric index-based weather insurance for risk management caused by/originating from natural disasters [10]. Another risk management tool in the corporate 
insurance industry put forth by UNSAR is insurance pricing as a market incentive for promotion of prevention and risk awareness and minimization [10].

Ongoing evaluation of the quality of services provided to customers to promote it, based on the insured's expectation and satisfaction, is one of the key methods in fostering a competitive environment in the insurance market to ensure a better performance level, as well as a better capacity to cope with a volatile market exposed to local and global economic changes [17].

Over the last few years, a growing trend of claims has arisen from quality control issues [25]. Several methods to mitigate this risk using corporate insurance should include:

1. Implementation of the following elements for a company's quality control policies, which guarantees for professional liability and general liability: alpha and beta testing, formal client acceptance procedure, prototype development, statistic quality control, supplier check process, TQM, writing and documenting quality control program, and a client's consent to each individual stage of the project.

2. Meeting one or more widely accepted industry standards: UL/CSA, ISO 9000, CE MARK, ANSI etc.

3. Performing pre-launch/pre-dissemination tests to protect clients against malicious codes and/or other security vulnerabilities in the company's services.

4. Availability of a plan to maintain documents/agreements for no less than 7 years.

5. Firms must create business continuity plans to manage this risk [26].

Lastly, we should mention several reasons to introduce TQM, quality control, and risk management in the corporate insurance industry [27]: prevent $\mathrm{E} \& \mathrm{O}$; follow the existing workflow/procedure; allow for an effective workflow/procedure; monitor the workload; and maintain customer service quality.

Author Contributions: Conceptualization, N.S.P. and M.R.G.; methodology, M.R.G.; software, M.R.G.; validation, N.S.P. and M.R.G.; formal analysis, N.S.P. and M.R.G.; investigation, N.S.P.; resources, N.S.P.; writing—original draft preparation, N.S.P.; writing — review and editing, M.R.G. All authors have read and agreed to the published version of the manuscript.

Funding: This research received no external funding.

Conflicts of Interest: The authors declare no conflict of interest.

\section{References}

1. Chen, J.; Chen, J.-H. Research in Establishment of Quality Control and Risk Management Systems. In Proceedings of the 28th International Symposium on Automation and Robotics in Construction (ISARC), Seoul, Korea, 29 June-2 July 2011; Available online: http://www.iaarc.org/publications/fulltext/S09-4.pdf (accessed on 20 August 2019). [CrossRef]

2. Allianz Global Corporate and Specialty. Global Claims Review 2018-The Top Causes of Corporate Insurance Losses. 2018. Available online: https://www.agcs.allianz.com/news-and-insights/reports/claims-in-focus. html (accessed on 20 August 2019).

3. Allianz Global Corporate and Specialty. Global Claims Review 2014-Loss Trend and Emerging Risk for Global Business. 2014. Available online: https:/www.agcs.allianz.com/content/dam/onemarketing/agcs/ agcs/reports/AGCS-Global-Claims-Review-2014.pdf (accessed on 20 August 2019).

4. Thomas, D. Risk management in NDT. Insight 1998, 40, 352.

5. Insurance Europe. European Insurance-Key Facts. 2018. Available online: https://www.insuranceeurope.eu/ sites/default/files/attachments/European\%20insurance\%20-\%20Key\%20facts\%20-\%20October\%202018.pdf (accessed on 20 August 2019).

6. UNSAR - Uniunea Națională a Societăților de Asigurare și Reasigurare din România. Gradul de Penetrare Pentru Asigurările de Catastrofă. 2013. Available online: https://ec.europa.eu/finance/consultations/2013/disastersinsurance/docs/contributions/non-registered-organisations/unsar_ro.pdf (accessed on 22 August 2019). 
7. Allianz Global Corporate and Specialty. Allianz Risk Barometer-Top Business Risk for 2019. 2019. Available online: https://www.agcs.allianz.com/content/dam/onemarketing/agcs/agcs/reports/Allianz-RiskBarometer-2019.pdf (accessed on 22 August 2019).

8. Insurance Information Institute. Available online: https://www.iii.org/article/insurance-options-for-greenbusinesses (accessed on 22 August 2019).

9. Insurance Information Institute. Available online: https://www.iii.org/article.infographic-businessinterruption-insurance (accessed on 22 August 2019).

10. Allianz Global Corporate and Specialty. Press Release-Fires and Explosions Cause Largest Losses for Business: Allianz Global Claims Analysis. 2018. Available online: https://www.agcs.allianz.com/news-andinsights/news/global-claims-review-2018.html (accessed on 22 August 2019).

11. Radu, N.; Naghi, L.E. Evoluția internațională a Incidenței Riscurilor Catastrofale. Rev. Stud. Fin. 2019, IV ,68-82. Available online: https://revista.isfin.ro/wp-content/uploads/2019/05/5.4_Nicoleta-Radu_RO.pdf (accessed on 2 September 2019).

12. Bawab, F.A.; Abbassi, G.Y. An application of Total Quality Management for the Insurance Companies Sector-A Case Study. Am. Soc. Eng. Manag. J. 1996, 207-214. Available online: http://www2.ju.edu.jo/sites/ Academic/abbasi/Lists/Published\%20Research/DispForm.aspx?ID=26 (accessed on 2 September 2019).

13. Surange, V.G. Implementation of Six Sigma to Reduce Cost of Quality: A Case Study of Automobile Sector. J. Fail. Anal. Prev. 2015, 15, 282-294. [CrossRef]

14. Jozsef, B.; Blaga, P. A more efficient production using quality tools and human resources management. Procedia Econ. Financ. 2012, 3, 681-689.

15. Heckman, P.E. Total Quality Management in Property/Causality Insurance: An Actuarial Respective. Discussion Papers-The Actuary as Business Manager. 1993. Available online: https:/www.casact.org/pubs/ dpp/dpp93/93dpp073.pdf (accessed on 2 September 2019).

16. Fataftah, S.K. The implementation of Total Quality Management (TQM) for the Insurance Companies in Palestine. Centre International de Hautes Etudes Agronomiques Mediterraneennes, Chania (Greece), Institut Agronomique Mediterranean. 2012. Available online: http://agris.fao.org/agris-search/search.do?recordID= QC2013200828 (accessed on 6 September 2019).

17. CMA (Capital Market Authority). Guiding Manual for the Minimum Standards of Quality Assurance for the Services Provided to the Customers of Insurance Companies and Brokers. Available online: https://www.cma.gov.om/Home/InsurancePublicationFileDownlad/1019 (accessed on 6 September 2019).

18. Terry, D. How Do Insurance Companies Track "Quality" Claim Handling? 2018. Available online: https://www.badfaithinsider.com/2018/02/insurance-companies-track-quality-claim-handling/ (accessed on 6 September 2019).

19. Sandquist, E.J. Kaizen and TQM also Have Roles to Play in Insurance Marketing. 2019. Available online: https://insuranceblog.accenture.com/kaizen-and-tqm-also-have-roles-to-play-in-insurance-marketing (accessed on 6 September 2019).

20. Crawford and Company. Crawford Netherlands Receives ISO Renewal again. 2019. Available online: https://www.claimsjournal.com/news/international/2005/09/16/59717.htm (accessed on 6 September 2019).

21. Crawford and Company. Press Release: Crawford and CompanyßAustralia achieves ISO 27001 Certification. 2018. Available online: https://au.crawfordandcompany.com/media/2369287/013218-crawford-australiaachieves-iso27001-certification-final.pdf (accessed on 6 September 2019).

22. Monetary Authority of Singapore. Guidelines on Risk Management Practices for Insurance Business-Core Activities. 2013. Available online: https://www.mas.gov.sg/-/media/MAS/Regulationsand-Financial-Stability/Regulatory-and-Supervisory-Framework/Risk-Management/Risk-ManagementGuidelines_Insurance-Core-Activities.pdf (accessed on 6 September 2019).

23. KPMG International. Our Relentless Focus on Quality-2016 Transparency Report. 2016. Available online: www.kpmg.com/transparency (accessed on 6 September 2019).

24. Ferguson, J. 4 Quality Control Tips That Can Reduce Claims. Available online: https://www.sadlerco.com/ quality-control/ (accessed on 16 September 2019).

25. Alexander, P. Best Practices Quality Management-Part I. 2011. Available online: https://www. insurancejournal.com/blogs/patalexander/2011/06/01/200428.htm (accessed on 6 September 2019). 
26. Zsidisin, G.A.; Melnyk, S.A.; Ragatz, G.L. An institutional theory perspective of business continuity planning for purchasing and supply management. Int. J. Prod. Res. 2005, 43, 3401-3420. [CrossRef]

27. Pryor, J. Why Risk Management and Quality Management Must Converge. 2014. Available online: https://www.irmi.com/articles/expert-commentary/risk-and-quality-management-convergence (accessed on 16 September 2019).

Publisher's Note: MDPI stays neutral with regard to jurisdictional claims in published maps and institutional affiliations.

(C) 2020 by the authors. Licensee MDPI, Basel, Switzerland. This article is an open access article distributed under the terms and conditions of the Creative Commons Attribution (CC BY) license (http://creativecommons.org/licenses/by/4.0/). 